\title{
ФАКТОР ІНТРАБДОМІНАЛЬНОЇ ГІПЕРТЕНЗІЇ ПРИ ГЕРНІОПЛАСТИЦІ ВЕНТРАЛЬНИХ ГРИЖ
}

\author{
B.I. Лупальцов, А.І. Ягнюк
}

Харківський наџіональний медичний університет, кафедра хірургії №3, м. Харків, Україна, ORCID ID: 0000-0003-2121-529X, e-mailsurgdis@ukr.net, ORCID ID: 0000-0001-7341-4982,e-mailyagnyuk@ukr.net

Резюме. Обгрунтування. Сучасні методики реконструкції черевної стінки, що грунтуються на розрізах апоневрозів прямих і косих м'язів живота в поєднанні з використанням сітчастих імплантів, дозволяють значно збільшувати залишковий обсяг черевної порожнини, але повністю не знімають питання необхідності контролю рівня внутрішньочеревного тиску.

Матеріали. Проведено аналіз результатів лікування 35 хворих 3 післяопераційними вентральними грижами (ПВГ). Жінок було 22 (62,9\%), чоловіків - $13(37,1 \%)$, середній вік становив 57,8 $\pm 6,4$ роки. Розміри грижових воріт за класифікацією European Hernia Society (2009) відповідали W2 у 8 (22,9\%), W3 - у 17(48,6\%), W4 - у 10 (28,5\%) пацієнтів.

Результати. Усім виконана комбінована герніопластика з використанням місцевих тканин і сітчастих імплантів 3 фіксацію onlay. Перед зшиванням країв грижового дефекту з метою профілактики абдомінального компартмент-синдрому визначався внутрішньочеревний тиск (BT) за Kron I.L. et al., 1984. Зшивання вважали допустимим при значенні ВТ не більше 150 мм вод. ст., що було можливим у 12 хворих (W2-W3). У 15 пацієнтів (W3-W4) при ВТ вище зазначеного рівня проводилося додаткове розсічення переднього листка піхви прямих м'язів живота. Рівень ВТ після операції не залежав від його вихідного рівня і виду операції і коливався в межах 132,5-129,5 5, 1-6,2 мм вод.ст. 3 метою контролю ранового процесу проведено УЗД післяопераційної рани. Відмічалася гіпоехогенна смужка між зшитими апоневротичними листками, яка при неускладненому перебігу набувала гіперехогенності, що свідчило про активний процес утворення рубцевої тканини і зменшення інфільтративних процесів у рані.

Висновки. Дослідження показало, що інтраопераційний контроль ВТ при герніопластиці ПВГ знижує ризик розвитку абдомінального компартмент-синдрому.

Ключові слова: абдомінальний компартмент-синдром, внутрішньочеревний тиск, післяопераційна вентральна грижа.

Вступ. Обгрунтування дослідження. Пластика грижового дефекту в пацієнтів $з$ післяопераційними вентральними грижами (ПВГ) неминуче призводить до підвищення внутрішньочеревного тиску (BT), що пов'язано з переміщенням у зменшений обсяг черевної порожнини органів, які перебували в грижовому мішку [1]. В експериментальних і клінічних дослідженнях показано, що навіть незначне підвищення ВТ може привести до порушень діяльності серцево-судинної системи, зниження спланхнічного кровотоку з подальшим порушенням перфузії і бар'єрної функції кишечника $[1,2]$.

Стійкий високий ВТ може зумовити розвиток одного $з$ найважчих післяопераційних ускладнень у хворих - абдомінального компартментного синдрому (АКС). За своєю суттю АКС є поліорганною недостатністю різного ступеня вираженості, яка обумовлена порушеннями центральної гемодинаміки і несе безпосередню загрозу життю хворого. Натяжна аутопластика великих і гігантських ПВГ, що виконана без урахування рівня ВТ і його контролю після операції, може привести до розвитку фатального АКС [3, 4].

Сучасні методики реконструкції черевної стінки, що грунтуються на розрізах апоневрозів прямих і косих м'язів живота в поєднанні з використан- ням сітчастих імплантів, дозволяють значно збільшувати залишковий обсяг черевної порожнини, але повністю не знімають питання необхідності контролю рівня ВТ. Тому профілактика АКС залишається однією з основних проблем герніопластики при ПВГ.

Матеріал і методи. В основу дослідження покладено аналіз результатів обстеження та лікування 35 хворих ПВГ. Серед пацієнтів чисельно переважали жінки - 22 (62,9\%), чоловіків було 13 (37,1\%); здебільшого це були особи працездатного віку (20-45 років - $5(14,3 \%), 46-60$ років - $17(48,6 \%), 60-75$ років - $11(31,4 \%)$, старше 75 років - $2(0,6 \%)$ пацієнтів), середній вік становив $57,8 \pm 6,4$ року.

Аналіз анамнестичних даних виявив, що ПВГ найчастіше формувалися після серединної лапаротомії $(54,3 \%)$, 3 переважною локалізацією грижових дефектів в мезо- і (або) епігастрії. Гнійні ускладнення 3 боку післяопераційної рани передували формуванню грижі у 15 (42,8\%) хворих, передчасне значне фізичне навантаження у побуті або на роботі - у 8 (22,8\%), релапаротомії - у $2(5,7 \%)$ пацієнтів. У інших випадках чітко визначити фактори, що сприяли грижеутворенню, не вдалося. 
Більш ніж у половини пацієнтів грижа була не вправимою - $11(31,4 \%)$ або защемленою - 9 $(25,7 \%)$, у $8(22,8 \%)$ - рецидивною.

Супутня патологія була виявлена у $2 / 3$ хворих $(65,7 \%)$. Найбільш часто зустрічалися захворювання серцево-судинної системи (гіпертонічна хвороба, ішемічна хвороба серця) - у 15 (42,8\%), хронічні запальні захворювання шлунка або кишечника - у 7 (20,0\%), ендокринні порушення (цукровий діабет, гіпотиреоз, ожиріння) - у 5 (14,3\%), варикозне розширення вен - у 9 (20,15\%), патологія сечостатевої (пієлонефрит, сечокам'яна хвороба) і дихальної систем (хронічні неспецифічні захворювання легенів) - по $2(5,7 \%)$.

Усі хворі піддавалися стандартному клініколабораторному обстеженню 3 оцінкою загального стану. Інструментальне дослідження включало оглядову рентгенографію та ультразвукову діагностику органів черевної порожнини і м'яких тканин черевної стінки (апарат Ultima Pro 30 (Радмір, Україна), конвексний і лінійний датчик). При підготовці хворого до операції проводилася УЗД м'язовоапоневротичних структур живота з оцінкою розміру грижових воріт, вмісту та наявності рідини в грижовому мішку, ступеня порушення кровотоку в ущемлених органах.

У всіх пацієнтів чітко лоціювалися грижові ворота $з$ витонченням м'язово-апоневротичного шару по їхній периферії до 3-8 мм. Розміри грижових воріт за класифікацією European Hernia Society (2009) відповідали W2 (5-10 см) - у 8 (22,9\%), W3 (10-15 см) - у 17 (48,6\%), W4 (більше 15 см) - у 10 (28,5\%), причому ущемлені грижі були малих розмірів (W2).

При УЗД черевної порожнини робився акцент на визначення ступеня розширення кишечника $\mathrm{i}$ виявлення вільної рідини, тому що внутрішньо порожнинні накопичення вмісту кишечника і газів у ньому $є$ основними факторами, що впливають на підвищення ВТ. Оцінювалися товщина кишкової стінки і іiі однорідність та активність перистальтики. Обсяг вільної рідини визначався умовно, з урахуванням іiі локалізації в черевній порожнині.

Рівень ВТ визначався перед ушиванням грижового дефекту, після виходу з наркозу і, за показаннями, у перші три дні після операції. Вимірювання ВТ проводили методом непрямої реєстрації за Kron I.L. et al. (1984). Після спорожнення сечового міхура через катетер Фолея в його порожнину вводилося 50 мл стерильного фізіологічного розчину, катетер приєднувався до апарату Вальдмана. Лобковий симфіз вважався нульовою точкою, а висота стовпчика рідини в міліметрах від нульової точки відповідала рівню ВТ.

Ступінь підвищення ВТ визначали за класифікацією J. Burch et al. (1996), згідно з якою 1 ступеню відповідає ВТ від 100 до 150 мм вод. ст.; 2 ступеню - від 150 до 250 мм вод. ст.; 3 ступеню більше 250 мм вод. ст. Наявність після операції ознак органної дисфункції на тлі підвищення ВТ розцінювалося як абдомінальний компартментсиндром. У цьому випадку моніторинг ВТ проводився кожні 6 годин і припинявся тільки тоді, коли він встановлювався нижче 100 мм вод. ст. у трьох послідовних вимірах. Всім пацієнтам проведена комбінована герніопластика 3 використанням місцевих тканин і сітчастих імплантів розмірами від $10 \times 15$ до $30 \times 30 \mathrm{~cm}$.

Комплекс профілактики АКС у планових хворих, крім інтраопераційного контролю ВТ, включав дієту 3 низьким вмістом клітковини протягом п'яти діб до операції та передопераційне носіння стягуючого бандажу. В ургентних випадках за показаннями проводилася інтубація тонкої кишки назогастро-інтестинальним зондом та дренування черевної порожнини.

Результати та обговорення. У всіх пацієнтів обсяг операції включав висічення післяопераційного рубця, ревізію вмісту грижового мішка (при защемленні оцінка життєздатності органу), зшивання апоневротичного шару, фіксація сітчастого імпланту onlay. При попередньому зіставленні країв грижового дефекту визначався ВТ у сечовому міхурі, а їх остаточне зшивання вважали допустимим при значенні ВТ не більше 150 мм вод. ст., що було можливим у 12 хворих (W2 -W3).

У 15 пацієнтів (W3 - W4) при підвищенні ВТ вище зазначеного рівня проводилося розсічення переднього листка піхви прямих м'язів живота, відступивши від краю грижових воріт не менше 4 см, чим досягалося збільшення ширини заднього листка їх піхв. Проводилось повторне вимірювання ВТ після зведення країв апоневрозу і при показнику ВТ не вище 150 мм вод. ст., зшивалися апоневротичні листки і відновлювалася біла лінія живота як анатомічна структура.

У 8 хворих з розміром грижових воріт W4 це виявилося не достатнім для досягнення необхідного безпечного показника ВТ при герніопластиці. У зв'язку з чим додатково проводилися послабляючи розрізи по фасції зовнішніх косих м'язів живота 3 обох сторін, що дозволяло знизити ВТ до рівня нижчого за 150 мм вод. ст за рахунок збільшення обсягу черевної порожнини.

Сітчастий імплант фіксувався в положенні onlay таким чином, щоб покривати всі утворені дефекти фасціальних футлярів, відступивши від їх краю дефекту не менше 5 см. У всіх пацієнтів після виходу 3 наркозу і відновлення спонтанного дихання не зафіксовано ВТ більше 200 вод рт. ст., а рівень сатурації становив не менше $92 \%$.

Динаміка зниження ВТ після операції не залежала від його вихідного рівня і виду операції. При відсутності ускладнень через 6 годин після операції ВТ становив 159,2 $\pm 6,8$ мм вод.ст., у наступні 24 години коливався в межах 132,5-129,5 \pm 5,1-6,2 мм вод.ст. Виразна тенденція ВТ до зниження відзначена вже на другу добу у більшості хворих (30) у міру відновлення перистальтики і активації пацієнтів.

УЗ-контроль післяопераційної рани вважали обов'язковим $з$ огляду на те, що герніопластика ПВГ проходить в умовах підвищеного ризику розвитку гнійно-запальних ускладнень, а саме на м'язовоапоневротичних тканинах 3 порушеними кровопостачанням й іннервацією та 3 імовірною латентною інфекцією. Розвиток інфекційного процесу сприяє 
підвищенню ригідності черевної стінки, обмежує активність хворого.

Ультразвукова картина черевної стінки першу добу після операції характеризувалася інфільтрацією i потовщенням тканини м'язовоапоневротичного шару (в середньому 1,5 рази від вихідного). Сітчастий імплант чітко визначався у вигляді щільної гомогенної гіперехогенної лінійної зони, що безпосередньо прилягає до апоневрозу передньої черевної стінки.

Також визначалася гіпоехогенна рідинна смужка між зшитими апоневротичними листками. Її ширина варіювала в залежності від термінів після операційного періоду і наявності ускладнень. При неускладненому перебігу вона максимально збільшувалася на 2-3 день, поступово зменшуючись з 3,5 $\pm 0,5$ мм до $1,1 \pm 0,4$ мм на 7-10 добу. Структура іiі набувала гіперехогенності, що свідчило про активний процес утворення рубцевої тканини і зменшення інфільтративних процесів у рані.

Навпаки, коли товщина гіпоехогенної міжапоневротичної смужки мала тенденцію до збільшення і становила 3,5-4 мм і більше, це розцінювалося як формування рідинних утворень (серома) і високий ризик розвитку гнійно-запальних ускладнень з боку рани. Серома післяопераційної рани сформувалися у $5(14,2 \%)$ пацієнтів, що може бути пов'язано 3 типом фіксації сітчастого імпланта і обсягом сепарації тканин черевної стінки. У трьох випадках їх ліквідація досягнута пункціями під контролем УЗД, а у двох випадках потребувалося додаткове активне дренування (аспірація) до 8-10 сут. Слід зазначити, що в трьох випадках сероми не мали клінічних ознак i тільки УЗ-моніторинг дозволив виявити наявність рідинних утворень у зоні герніопластики.

Нагноєння післяопераційної рани було у 1 $(2,68 \%)$ хворого в зоні розташування сітчастого імпланта, що не привело до його видалення. Інтраабдомінальних ускладнень, міграції сітчастого імпланта в черевну порожнину або виникнення кишкових нориць внаслідок контакту кишки 3 імплантом не відзначено.

До ускладнень післяопераційного періоду слід віднести у 4 хворих на 2-3 добу появу клінічних ознак післяопераційного парезу кишечника, що підтверджено УЗД (розширення просвіту товстого і тонкого кишечника, наявність надлишкової кількості газу) і показниками ВТ, які не мали тенденції до зниження і дещо збільшилися. Назогастральне зондування i ректальний дренаж 3 введенням прокінетіков (метоклопрамід, прозерин) у короткі терміни купірували ці явища. Ці методи, на наш погляд, досить ефективні при лікуванні підвищення ВТ 1-2-го ступеня.

У одного пацієнта з защемленою грижею на тлі захворювання печінки післяопераційне підвищення ВТ було обумовлювано асцитом, що швидко збільшувався. Під контролем УЗД через окремий пункційний отвір черевної порожнини йому проведено дренування мікроіррігатором, що ефективно знизило ВТ і дозволило уникнути розвитку АКС.
У 1 (2,68\%) пацієнта відмічена нефатальна ТЕЛА 3 клінічними проявами у вигляді плевропневмоніі. Летальних випадків не було.

Таким чином, проблема лікування ПВГ, особливо великих розмірів, дотепер не вирішена та $є$ актуальною. Це пов'язане не в останню чергу із загрозою розвитку абдомінального компартментсиндрому у результаті переміщення внутрішніх органів у зменшений об’єм черевної порожнини. Застосування варіантів традиційних методик ендопротезування (inlay, onlay, sublay) не вирішує всі питання підвищеного ВТ, часто вимушує застосовувати сітчасті імпланти без відновлення мязовоапоневротичного шару черевної стінки. Тому як варіант відновлення черевної стінки при ПВГ можна рекомендувати виконання комбінованої протезуючої герніопластики під інтраопераційним контролем ВТ 3 додатковим розсіченням піхви прямих м'язів живота, що дозволяє оцінити рівень підвищення ВТ під час закриття черевної порожнини, тим самим запобігаючи розвитку компартмент-синдрому.

\section{Висновки:}

1. Інтраопераційний контроль ВТ під час герніопластики післяопераційних вентральних гриж дозволяє значно знизити ризик виникнення абдомінального компартмент-синдрому у ранньому післяопераційному періоді.

2. УЗ-моніторинг зони герніополастики в післяопераційному періоді сприяє своєчасній діагностиці ранових запальних ускладнень та рідинних скупчень.

\section{References:}

1. Kirkpatrick WA, Nickerson D, Roberts DJ et al. Intraabdominal hypertension and abdominal compartment syndrome after abdominal wall reconstruction: quaternary syndromes. Scandinavian Journal of Surgery. 2017; 106(2):97-106. doi:10.1177/145749691 6660036.

2 Reintam Blaser A, Regli A, De Keulenaer B et al. Incidence, risk factors, and outcomes of intra-abdominal hypertension in critically Ill patients - a Prospective Multicenter Study (IROI study). Crit Care Med. 2019; 47(4):535-542. doi:10.1097/CCM.000000000 00036 23.

3. Hong JJ. Prospective study of the incidence and outcome of intra-abdominal hypertension and the abdominal compartment syndrome. Brit J Surg. 2002; 89(5):591-599.

4. Morozov DA, Filippov $\mathrm{YuV}$ et al. Sindrom intraabdominal noj gipertenzii. Vestnik khirurgii. 2011; 1:97-101. 


\section{УДК 617.55-007.43-089.44:616.381-008.718-07 \\ ФАКТОР ИНТРАБДОМИНАЛЬНОЙ ГИПЕР- ТЕНЗИИ ПРИ ГЕРНИОПЛАСТИКЕ ВЕН- ТРАЛЬНЫХ ГРЫЖ}

\section{В.И. Лупальцов, А.И. Ягнюк}

Харьковский национальный медицинский университет, кафедра хирургии №3,

2. Харьков, Украина,

ORCID ID: 0000-0003-2121-529X,

e-mailsurgdis@ukr.net,

ORCID ID: 0000-0001-7341-4982,

e-mailyagnyuk@ukr.net

Резюме. Обоснование. Современные методики реконструкции брюшной стенки, основанные на разрезах апоневрозов прямых и косых мышщ живота в сочетании с использованием сетчатых имплантов, позволяют значительно увеличивать остаточный объем брюшной полости, но полностью не снимают вопрос о необходимости контроля уровня внутрибрюшного давления.

Материалы. Проведен анализ результатов лечения 35 больных с послеоперационными вентральными грыжами (ПВГ). Женщин было 22 $(62,9 \%)$, мужчин - 13 (37,1\%), средний возраст составил $57,8 \pm 6,4$ года. Размеры грыжевых ворот по классификации European Hernia Society (2009) соответствовали W2 - у 8 (22,9\%), W3 - у 17 (48,6\%), W4 - у $10(28,5 \%)$ пациентов.

Результаты. Всем выполнена комбинированная герниопластика с использованием местных тканей и сетчатых имплантов с фиксацией onlay. Перед сшиванием краев грыжевого дефекта с целью профилактики абдоминального компартментсиндрома определялось внутрибршное давление (ВД) по Kron I.L. et al., 1984. Сшивание считали допустимым при значении ВД не более 150 мм вод. ст., что было возможным у 12 больных (W2-W3). У 15 пациентов (W3-W4) при ВД выше указанного уровня проводилось дополнительное рассечение переднего листка влагалища прямых мышщ живота. Уровень ВД после операции не зависел от его исходного уровня и вида операции и колебался в пределах 132,5$129,5 \pm 5,1-6,2$ мм вод. С целью контроля раневого процесса проведения УЗИ послеоперационной раны. Отмечалась гипоэхогенная полоска между сшитыми апоневротическими листками, которая при отсутствии осложнений приобреталась гиперэхогенность, что свидетельствовало об активном процессе образования рубцовой ткани и уменьшении инфильтративных процессов в ране.

Выводы. Исследование показало, что интраоперационный контроль ВД при герниопластике ПВГ снижает риск развития абдоминального компартментсиндрома.

Ключевые слова: абдоминальный компартмент-синдром, внутрибрюшное давление, послеоперационная вентральная грижа.

\section{UDC 617.55-007.43-089.44:616.381-008.718-07 FACTOR OF INTRA-ABDOMINAL HYPERTENSION IN VENTRAL HERNIA REPAIR}

\author{
V.I. Lupaltsov, A.I. Yahniuk \\ Kharkiv National Medical University, Surgery \\ Department №3, Kharkov, Ukraine, \\ ORCID ID: 0000-0003-2121-529X, \\ e-mailsurgdis@ukr.net, \\ ORCID ID: 0000-0001-7341-4982, \\ e-mailyagnyuk@ukr.net
}

Abstract. Rationale. Modern techniques of abdominal wall reconstruction based on incisions of rectus abdominis and oblique muscles aponeurosis, in combination with the use of polypropylene endoprostheses allow to significantly increase the residual volume of the abdominal cavity, but do not completely eliminate the need to control the level of intra-abdominal pressure.

Materials. Analysis of the results of the treatment of 35 patients with postoperative ventral hernia $(\mathrm{PVH})$ was performed. Among the patients, there were 22 women $(62,9 \%)$ and 13 men $(37,1 \%)$, the average age was $57,8 \pm 6,4$ years. The size of the hernia gate according to the classification of the European Hernia Society (2009) corresponded to W2 - in 8 cases $(22,9 \%)$, W3 - in 17 cases $(48,6 \%)$, W4 - in 10 cases $(28,5 \%)$. PVH was most often formed after midline laparotomy - $(54,3 \%)$, with the predominant localization of hernia defects in the meso- and (or) epigastrium. Purulent complications of the postoperative wound preceded the formation of hernia in $15(42,8 \%)$ cases, premature significant physical activity at home or at work - in $8(22,8 \%)$ cases, relaparotomy - in $2(5,7 \%)$ cases. In other cases, the factors that contributed to hernia formation could not be clearly identified. During the preparation of the patient for surgery, an ultrasound of the musculo-aponeurotic structures of the abdomen was performed to assess the size of the hernia gate, the content and fluid presence in the hernia sac, the degree of blood flow disorders in the affected organs.

Results. All patients underwent combined hernia repair using local tissues and mesh polypropylene endoprostheses with onlay fixation. Before suturing the edges of the hernia defect, in order to prevent abdominal compartment syndrome, intra-abdominal pressure (IAP) by Kron I.L. et al.,1984 was measured. Suturing was considered acceptable at IAP level not exceeding $150 \mathrm{~mm} \mathrm{Hg}$, which was possible for 12 patients (W2-W3). 15 patients (W3-W4) with IAP above this value underwent additional dissection of the vagina anterior leaf of the rectus abdominis, not less than $4 \mathrm{~cm}$ from the edge of the hernia gate, which allowed to achieve an increase in the width of the vagina posterior leaf. Additional IAP measurement was performed after aponeurosis edges connection, and at the IAP level not higher than $150 \mathrm{~mm} \mathrm{Hg}$ aponeurotic leaves were sutured and the white line of the abdomen as an anatomical structure was restored.

IAP level after surgery did not depend on its initial value and surgery type and lay in a range of 132,5$129,5 \pm 5,1-6,2 \mathrm{~mm} \mathrm{Hg}$. A clear tendency of IAP to decrease was observed already on the second day in most 
cases (30), as peristalsis was restored and patients were activated.

In order to control the wound process, an ultrasound of the postoperative wound was performed. There was a hypoechoic band between the sutured aponeurotic leaves, which in complicated course showed hyperechogenicity, indicating an active process of scar tissue formation and decrease of the infiltrative processes in the wound. On the contrary, when the thickness of the hypoechoic interaponeurotic band tended to increase reaching 3,5-4 $\mathrm{mm}$ or more, it was regarded as fluid formations (seroma) and a high risk of purulent-inflammatory complications of the wound.

Conclusions. The research showed that intraoperative control of IAP in PVH repair reduces the risk of abdominal compartment syndrome. Postoperative ultrasound monitoring of the hernia repair surgery area allows to diagnose signs of wound inflammatory complications in a timely manner.

Keywords: abdominal compartment syndrome, intra-abdominal pressure, postoperative ventral hernia.

Стаття надійшла в редакцію 14.05.2020 p. 